\title{
Effect of Various In-furnace Conditions on Blast Furnace Hearth Drainage
}

\author{
Koki NISHOKA, Takayuki MAEDA and Masakata SHIMIZU \\ Department of Materials Science and Engineering, Faculty of Engineering, Kyushu University, 6-10-1 Hakozaki, Higashi-ku, \\ Fukuoka 812-8581 Japan. E-mail: kouki@zaiko.kyushu-u.ac.jp
}

(Received on March 9, 2005; accepted on June 13, 2005)

\begin{abstract}
Stable blast furnace operation is required to reduce energy consumption and $\mathrm{CO}_{2}$ emission in iron and steelmaking industry. For the stable blast furnace operation, precise controlled drainage is one of the important factors. Therefore, in this work, the effect of coke diameter, void fraction, coke diameter distribution, coke free space, impermeable zone, slag viscosity in a blast furnace hearth on drainage rates, gas-slag and slag-iron interfaces shapes and maximum gas-slag interfaces height were examined with a three-dimensional mathematical model.

The results indicate that the conditions of the peripheral region at the taphole level determine the residual slag volume. The packed bed in the region $2.0 \mathrm{~m}$ from the taphole has about $50 \%$ of contribution to the residual slag volume. The void fraction change has the largest effect on the gas-slag interfaces height. The coke diameter distribution has little effect on the total drainage rate as well as the coke diameter of the uniform packed bed, coke free space, and impermeable zone bellow the taphole level. The taphole conditions dominate the total drainage rate under the terms of the assumed blast furnace conditions. The conditions of the peripheral region in the hearth determine the drainage rate patterns of the iron and slag. The peripheral region's permeability can be predicted from the drainage rate patterns of iron and slag, if precise measurement of the drainage rate patterns can be achieved. A drainage pattern, whether iron drains prior to slag or slag drains prior to iron, is largely affected by a drainage interval.
\end{abstract}

KEY WORDS: iron and slag flow; residual slag volume; numerical simulation; VOF method; blast furnace hearth; ironmaking; coke diameter; void fraction; slag viscosity.

\section{Introduction}

Japanese iron and steelmaking industry has to reduce $\mathrm{CO}_{2}$ emission by $11.5 \%$ in 2010 relative to the level of emissions in 1990. Stable blast furnace operation is required to reduce energy consumption and $\mathrm{CO}_{2}$ emission in iron and steelmaking industry. For the stable blast furnace operation, precise controlled drainage is one of the important factors. ${ }^{1-4)}$

Many researchers attempted to solve the issues by using experimental and mathematical models. ${ }^{1-11)}$ However, there are many problems to understand drainage behavior in a blast furnace hearth because several important hearth values such as coke diameter, void fraction, and levels of iron and slag cannot be measured during a tap. Because of these issues, the effects of the various in-furnace conditions on the stable operation were not examined well.

In a previous paper, ${ }^{12)}$ we developed a three-dimensional mathematical model. The mathematical model consists of two sub-models that are pressure drop evaluation model in a taphole and fluid flow estimation model in a hearth so that the mathematical model can describe drainage rate variation caused by taphole diameter expansion during a tap due to a ware of clay and variation of various in-furnace conditions which have never been done so far. The mathematical model can also describe various drainage behaviours in a hearth such as temporal variation of iron and slag drainage rates, gas-slag and slag-iron interfaces shapes, and drainage time with a high degree of accuracy.

Therefore, in this work, the effect of coke diameter, void fraction, coke diameter distribution, coke free space, impermeable zone, slag viscosity in a blast furnace hearth on drainage rates, gas-slag and slag-iron interfaces shapes and maximum gas-slag interfaces height were examined with the mathematical model.

\section{Mathematical Modelling}

\subsection{Governing Equations for Fluid Flow Estimation in a Hearth}

A three-dimensional mathematical model considers momentum conservation for a fluid (iron, slag) flow at unsteady state. ${ }^{12)}$ In a coke bed, advection term, pressure gradient term and drag interaction term were considered. Liquid-solid drag force in the coke bed was evaluated by Kozeny-Carman's expression. ${ }^{13)}$ In a coke free space, Navier-Stokes's equation, which considers advection term, diffusion term and pressure gradient term, was used as a governing equation. 


\subsection{Representation of Surfaces and Interfaces}

For the determination of fluid properties in each computational cell, it is necessary to compute the proportion of gas, iron and slag in each cell. Gas-slag and slag-iron interfaces should be identified exactly. The VOF method ${ }^{14,15)}$ was applied for the calculation of interfaces (gas-slag and slag-iron). A unit value of $\mathrm{VOF}_{1}$ would correspond to a cell full of liquid. A unit value of $\mathrm{VOF}_{2}$ would correspond to a cell full of iron. Cells with $\mathrm{VOF}_{2}$ values between zero and one must then contain an iron-slag interface. Slag iron ratio of each cell is calculated from $\mathrm{VOF}_{1}$ and $\mathrm{VOF}_{2}$. Properties of each cell were determined by the weighted average of the fluids (gas, slag, iron) existed in the cell.

\subsection{Drainage Rate Estimation from a Taphole}

When a taphole is assumed a pipe having $D(\mathrm{~m})$ in diameter, $L(\mathrm{~m})$ in taphole length, $e(\mathrm{~m})$ in surface roughness of the taphole, friction factor $f^{16)}$ is derived from Eq. (1).

$$
f=\frac{0.0626}{\left[\log \left(\frac{e}{3.7 D}+\frac{5.74}{R e^{0.9}}\right)\right]^{2}}
$$

Considering the force balance of shearing force at the wall of the taphole and the pressure difference between the inlet and outlet of the taphole, the total drainage rate of iron and slag $\bar{u}$ is derived from Eq. (2)

$$
\bar{u}=\sqrt{\frac{\Delta P D}{2 f \rho L}}
$$

Under typical blast furnace conditions, taphole conditions suppose to dominate the drainage rate $(\bar{u})$. Therefore, these parameters (taphole diameter $D$, taphole length $L$, and surface roughness of the taphole $e$ ) are obtained from a total drainage rate of an actual blast furnace, which strongly related to taphole conditions. ${ }^{12)}$

\subsection{Calculation Procedure}

Difference equations were derived from the governing equations based on the finite difference method. The difference equations were solved by the HSMAC method ${ }^{14,15)}$ on staggered grids of a three-dimensional cylindrical coordinate system. The VOFs were solved with the donor accepter method. ${ }^{15)}$ In this model, numerical analysis proceeds as follows.

1) Molten iron and slag dropped on the iron and slag surface, respectively.

2) Fluid properties in the taphole were given by the weighted average of iron and slag properties existed in the nearest cell to the taphole. A total drainage rate from the taphole was calculated by Eq. (2).

3) Velocity distribution of iron and slag in the hearth was calculated by the fluid flow estimation model ${ }^{12}$ with the total drainage rate as a boundary condition.

4) Gas-slag and slag-iron interfaces moved according with the velocity distribution.

5) Inflow pressure for the taphole was obtained from the fluid flow estimation model.
6) Multiplying the total drainage rate by volume fractions of iron and slag in the nearest cell to the taphole gave iron and slag drainage rates, respectively.

7) These steps were repeated until the gas-slag interface reaches the taphole.

8) When the gas-slag interface reached the taphole, the taphole was closed. If the fluid flow behavior and drainage rates pattern did not reach quasi-steady state, the other taphole was opened, and above procedure was repeated for the next tap.

\subsection{Conditions for Calculations}

Conditions for calculations in this work are: Hearth temperature were $1773 \mathrm{~K}$. Slag composition was $0.3 \mathrm{mass} \%$ $\mathrm{FeO}, 34$ mass $\% \mathrm{SiO}_{2}, 15$ mass $\% \mathrm{Al}_{2} \mathrm{O}_{3}, 42$ mass $\% \mathrm{CaO}$ and $6.5 \mathrm{mass} \% \mathrm{MgO}$. Iron and slag properties were given by a function of their composition and temperature. ${ }^{17}$ Outflow pressure for a taphole was fixed to $1.0 \times 10^{5} \mathrm{~Pa}$; inflow pressure for the taphole was obtained from the fluid flow estimation model at each time. In this work, molten iron and slag uniformly dropped on iron and slag surfaces respectively, because effects of iron and slag dropping patterns on the surfaces were negligible. Interactive force between iron and slag during iron passing through slag phase was not considered in this model. Numbers of grid cells were $15(r) \times 22(z) \times 32(\theta)$, and time increment was set small enough values to satisfy numerical stability.

Conditions of an assumed blast furnace in Secs. 3.1-3.6 are shown in Table 1. Hearth diameter of the blast furnace is $14 \mathrm{~m}$, distance between bottom of the hearth and the taphole is $3.0 \mathrm{~m}$, quantity of production is $10000 \mathrm{t} / \mathrm{d}$, and slag ratio is $300 \mathrm{~kg} / \mathrm{thm}$. In the calculations, only taphole diameter was varied as drainage time, taphole length and surface roughness of taphole were fixed during calculations. Iron and slag were tapped from two tapholes located opposite angle alternately until drainage behavior reached quasisteady state.

Conditions in Sec. 3.7 designed for Kobe 3BF to investigate the effect of drainage interval and taphole location are shown in Table 2. Inner volume of the blast furnace is $1845 \mathrm{~m}^{3}$, hearth diameter is $9.6 \mathrm{~m}$, distance between bottom of the hearth and the taphole is $1.2 \mathrm{~m}$, quantity of production is $4150 \mathrm{t} / \mathrm{d}$ and slag ratio is $227 \mathrm{~kg} / \mathrm{thm}$. Iron and slag were tapped from two tapholes located 40 degrees apart from each other alternately until drainage behavior reached quasi-steady state.

Table 1. Conditions for calculation in Secs. 3.1-3.6.

\begin{tabular}{|l|c|}
\hline Hearth temperature $(\mathrm{K})$ & 1773 \\
\hline Inner volume of blast furnace $\left(\mathrm{m}^{3}\right)$ & 5000 \\
\hline Hearth diameter $(\mathrm{m})$ & 14 \\
\hline Taphole location from bottom $(\mathrm{m})$ & 3.0 \\
\hline Quantity of production (tonnes/d) & 10,000 \\
\hline Slag ratio $(\mathrm{kg} / \mathrm{thm})$ & 300 \\
\hline Taphole length $(\mathrm{m})$ & 2.5 \\
\hline Taphole surface roughness $(\mathrm{mm})$ & 1.0 \\
\hline Initial taphole diameter $(\mathrm{mm})$ & 53.0 \\
\hline Expansion rate of taphole diameter $(\mathrm{m} / \mathrm{s})$ & $1.736 \times 10^{-6}$ \\
\hline Gas-Slag interface pressure $(\mathrm{Pa})$ & $4.5 \times 10^{5}$ \\
\hline Outflow pressure for taphole $(\mathrm{Pa})$ & $1.0 \times 10^{5}$ \\
\hline
\end{tabular}


Table 2. Conditions for calculation in Sec. 3.7.

\begin{tabular}{|l|c|}
\hline Hearth temperature $(\mathrm{K})$ & 1773 \\
\hline Inner volume of blast furnace $\left(\mathrm{m}^{3}\right)$ & 1845 \\
\hline Hearth diameter $(\mathrm{m})$ & 9.6 \\
\hline Taphole location from bottom $(\mathrm{m})$ & 1.2 \\
\hline Quantity of production (tonnes/d) & 4,150 \\
\hline Slag ratio $(\mathrm{kg} / \mathrm{thm})$ & 227 \\
\hline Taphole length $(\mathrm{m})$ & 2.5 \\
\hline Taphole surface roughness $(\mathrm{mm})$ & 1.0 \\
\hline Initial taphole diameter $(\mathrm{mm})$ & 41.6 \\
\hline Expansion rate of taphole diameter $(\mathrm{m} / \mathrm{s})$ & $1.493 \times 10^{-6}$ \\
\hline Gas-Slag interface pressure $(\mathrm{Pa})$ & $4.1 \times 10^{5}$ \\
\hline Outflow pressure for taphole $(\mathrm{Pa})$ & $1.0 \times 10^{5}$ \\
\hline
\end{tabular}

\section{Results and Discussions}

Under various in-furnace conditions, the effect of coke diameter $(15,20,30,40,60 \mathrm{~mm})$, void fraction $(0.2,0.25$, $0.3,0.4,0.5)$, coke free space height $(0.0,1.2,2.2 \mathrm{~m})$, impermeable zone height $(0.0,1.2,2.2 \mathrm{~m})$, coke diameter distribution, slag viscosity $(0.27,0.54,1.08 \mathrm{~Pa} \cdot \mathrm{s})$, drainage interval $(0,600,1200,1620,2400 \mathrm{~s})$ on iron and slag drainage rates, residual iron and slag volume, and temporal variation of interfaces shapes were investigated by using the mathematical model. Base conditions are; Uniform packed bed with $30 \mathrm{~mm}$ of coke diameter and 0.3 of void fraction, iron and slag properties correspond to $1773 \mathrm{~K}, 0 \mathrm{~s}$ of drainage interval. The results of the base conditions are shown in Fig. 1, which were validated with an actual operational data of Chiba No. 6 blast furnace in the previous paper. $^{12)}$

\subsection{Effect of Coke Diameter in the Hearth}

Figure 2 shows temporal variation of total, iron and slag drainage rates during a tap with $15 \mathrm{~mm}$ and $60 \mathrm{~mm}$ of coke for the packed bed, respectively. Total drainage rate of the base condition is also shown in Fig. 2. The maximum difference of the total drainage rate between the case with $15 \mathrm{~mm}$ of coke and the base condition is $8.38 \%$, and the maximum difference of the total drainage rate between the case with $60 \mathrm{~mm}$ of coke and the base condition is $4.96 \%$. Therefore, the coke diameter has little effect on the total drainage rate. Regarding the iron and slag drainage rates, as the coke diameter of the packed bed increases, one or two intersections of the iron and slag drainage rates move toward the beginning of the tap. The reason is that an increase of the coke diameter causes an increase of the effect of the gravitational force, relatively. Then, the iron-slag interface tends to keep in a horizontal position. As the result, iron flows prior to slag at the first half of the tap. In contrast, at the second half of the tap, slag drains more than iron to achieve their mass balances.

Figure 3 shows temporal variation of gas-slag and iron-slag interfaces height during the tap with 15 and $60 \mathrm{~mm}$ of coke, respectively. When the coke diameter changes from 60 to $15 \mathrm{~mm}$, the highest and lowest points of the gas-slag interface (line A and B in Fig. 3) move upward about 1.4 and $1.0 \mathrm{~m}$ respectively in about $7200 \mathrm{~s}$. In contrast, the lowest point of iron-slag interface (D) moves downward about $1.0 \mathrm{~m}$ in about $7200 \mathrm{~s}$. Therefore, when the coke diameter changes from 60 to $15 \mathrm{~mm}$, the slag layer
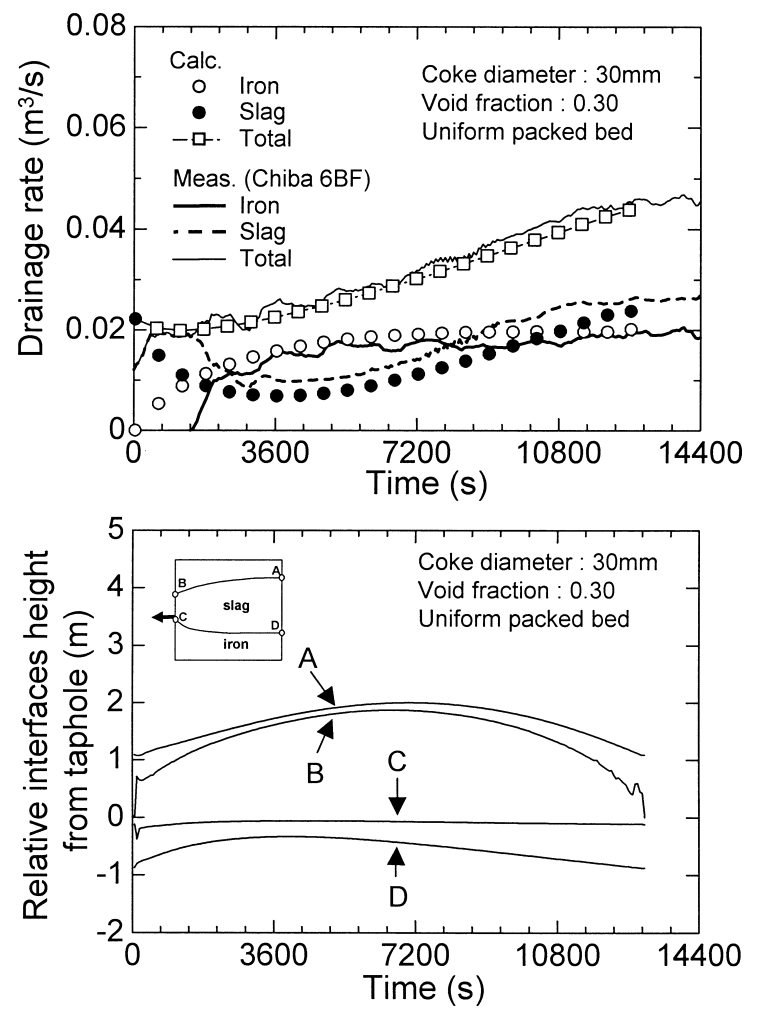

Fig. 1. Temporal variation of iron, slag and total drainage rate and relative interfaces height from taphole under base condition.
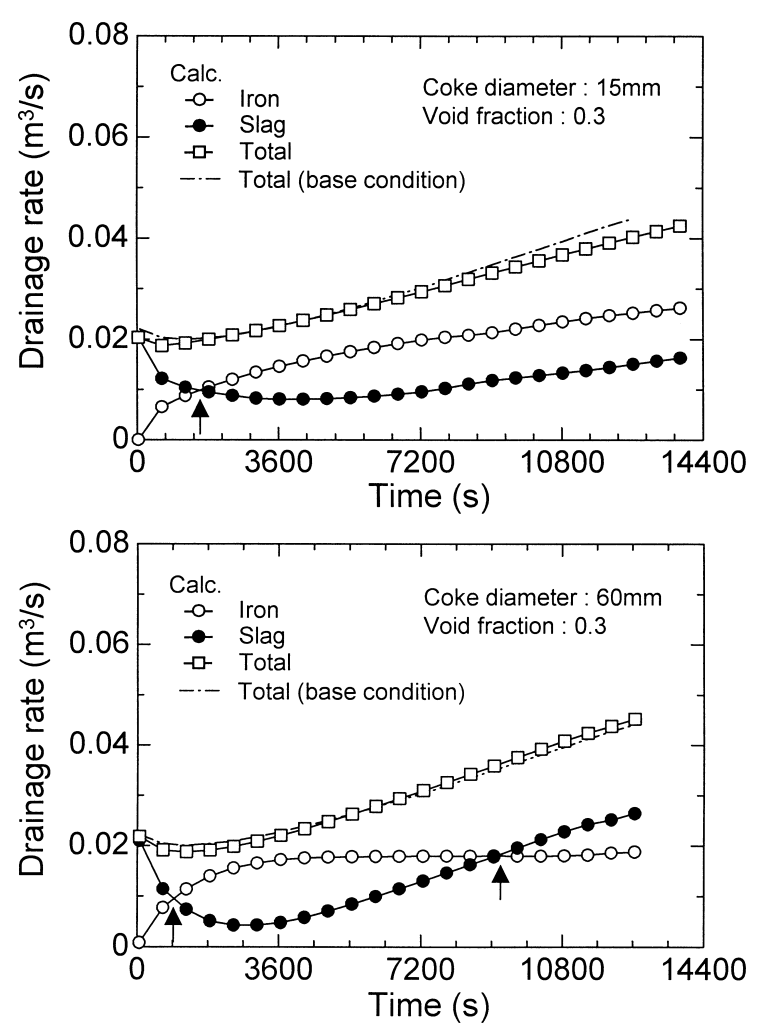

Fig. 2. Effect of coke diameter on temporal variation of iron, slag and total drainage rate. Coke packed bed is uniform.

expands both upward and downward, and the maximum slag layer thickness increases about $2.4 \mathrm{~m}$.

The effect of coke diameter on iron and slag average thickness and maximum gas-slag interfaces height are 

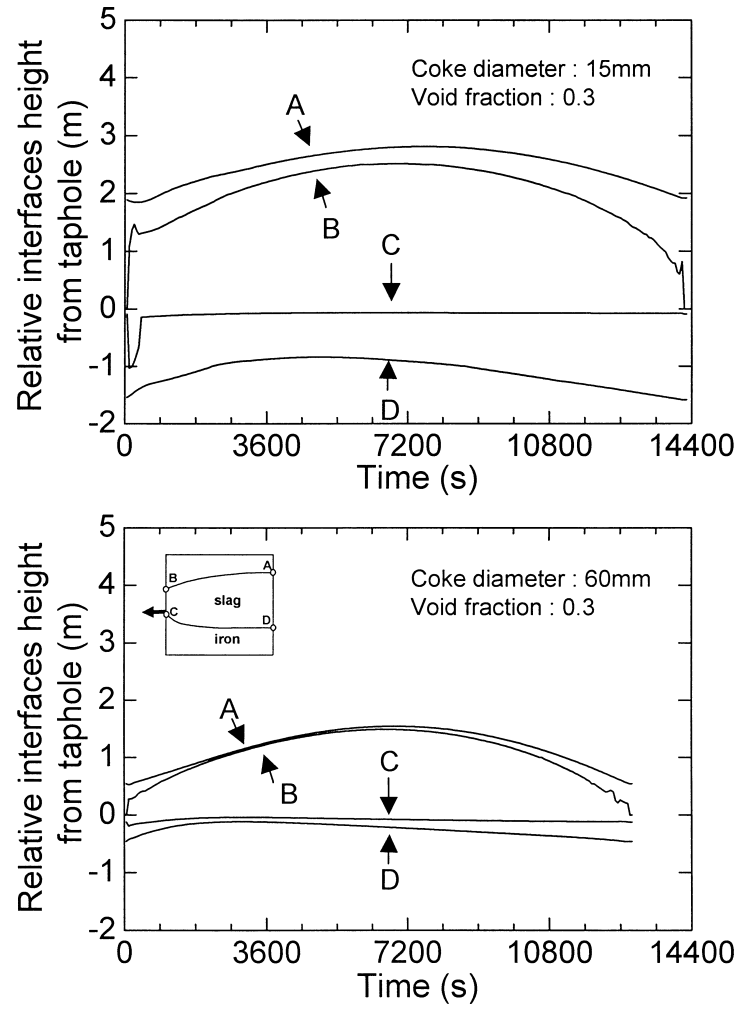

Fig. 3. Effect of coke diameter on gas-slag and slag-iron interfaces height.

shown in Fig. 4. As the coke diameter increases, the thickness of the slag layer and the maximum gas-slag interfaces height decrease. A decrease in the coke diameter causes a decrease of permeability in the packed bed, a decrease of the inflow pressure for the taphole, and a decrease of the drainage rate, as the result, an increase of the drainage time.

\subsection{Effect of Void Fraction in the Hearth}

Figure 5 shows temporal variation of total, iron and slag drainage rates during a tap with 0.2 and 0.5 of void fraction in the packed bed, respectively. The maximum difference of the total drainage rate between the case with 0.2 of void fraction and the base condition is $9.88 \%$, and the maximum difference of the total drainage rate between the case with 0.5 of void fraction and the base conditions is only $2.01 \%$. Therefore, the void fraction has also little effect on the total drainage rate as well as coke diameter. Regarding the iron and slag drainage rates, as the void fraction in the packed bed increases, two intersections of the iron and slag drainage rates move toward the beginning of the tap as in the case of the coke diameter change, because an increase of the void fraction causes an increase of the effect of the gravitational force as well as that of the coke diameter.

Figure 6 shows temporal variation of gas-slag and iron-slag interfaces height during the tap with 0.2 and 0.5 of void fraction, respectively. The effect of void fraction on iron and slag average thickness and maximum gas-slag interfaces height are shown in Fig. 7. An increase of the void fraction results in decreases of the slag layer thickness and the maximum gas-slag interfaces height. The effect of the void fraction is larger than that of the coke diameter on the interfaces height, because increasing void fraction in the hearth provides increases of both permeability and storage
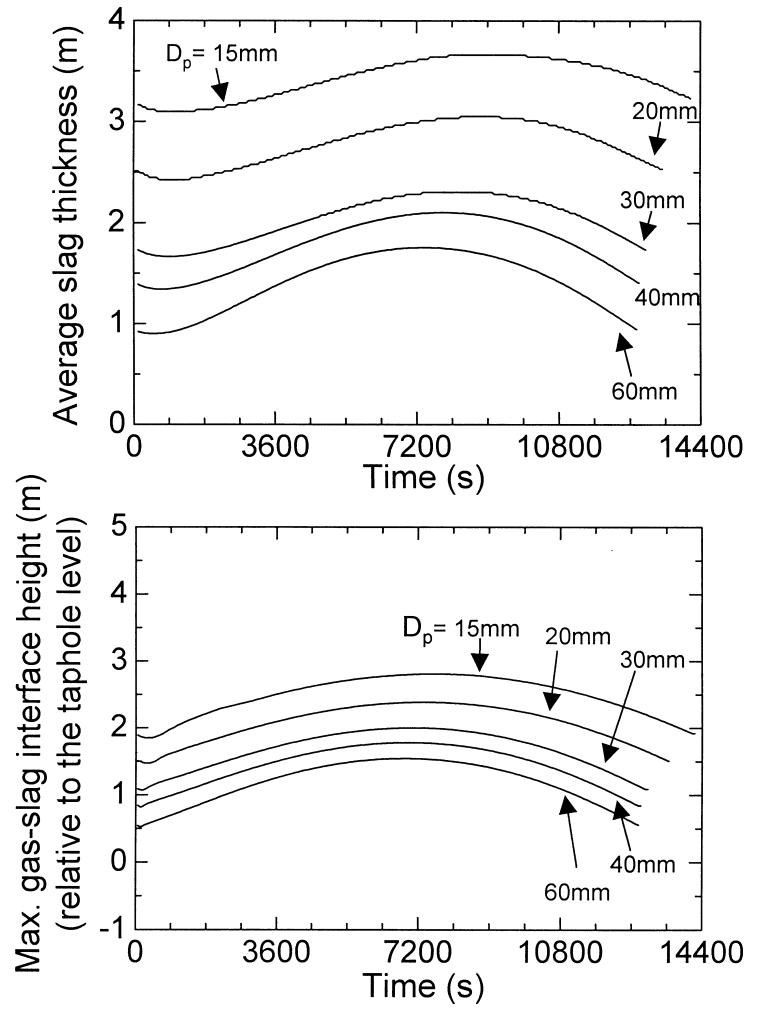

Fig. 4. Effect of coke diameter on average thickness of slag, and maximum gas-slag interface height.
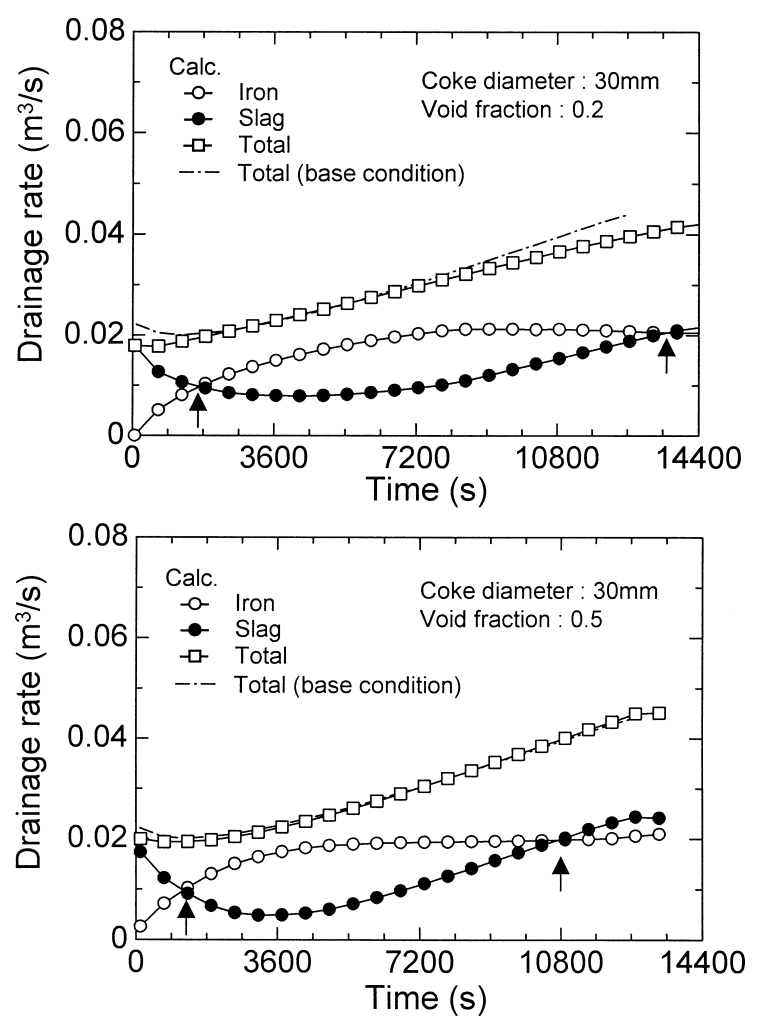

Fig. 5. Effect of void fraction on temporal variation of iron, slag and total drainage rate. Coke packed bed is uniform.

capacity for slag volume per unit volume in the hearth, however, increasing coke diameter provides only an increase of permeability in the hearth. The average thickness of slag layer decreased about $3.0-4.0 \mathrm{~m}$ and the maximum gas-slag interface height decreased about $3.0 \mathrm{~m}$ by varying 

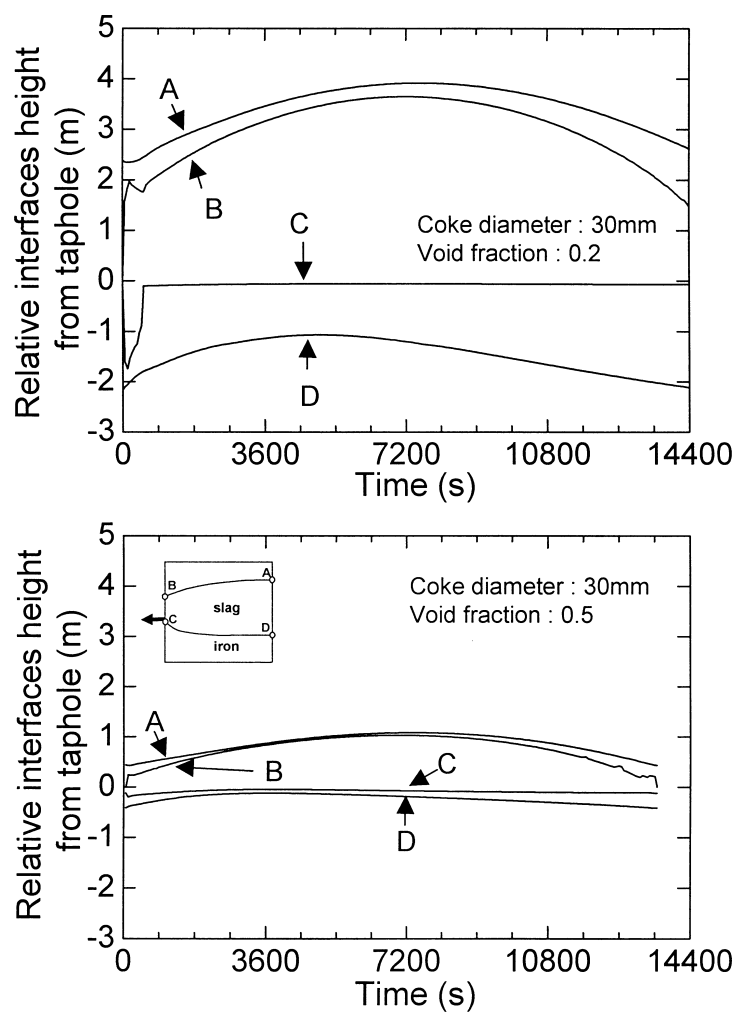

Fig. 6. Effect of void fraction on gas-slag and slag-iron interface height.
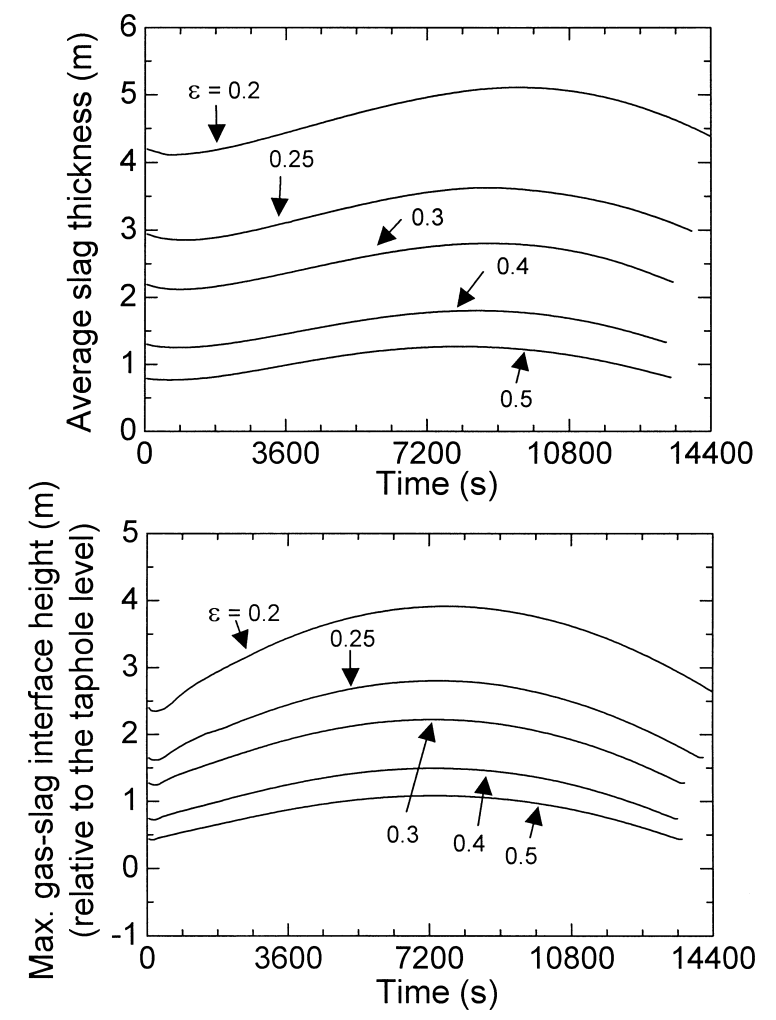

Fig. 7. Effect of void fraction on average thickness of slag and maximum gas-slag interface height.

the void fraction from 0.2 to 0.5 .

\subsection{Effect of Coke Free Space in the Hearth}

Figure 8 shows temporal variation of drainage rates, and Fig. 9 shows temporal variation of gas-slag and iron-slag

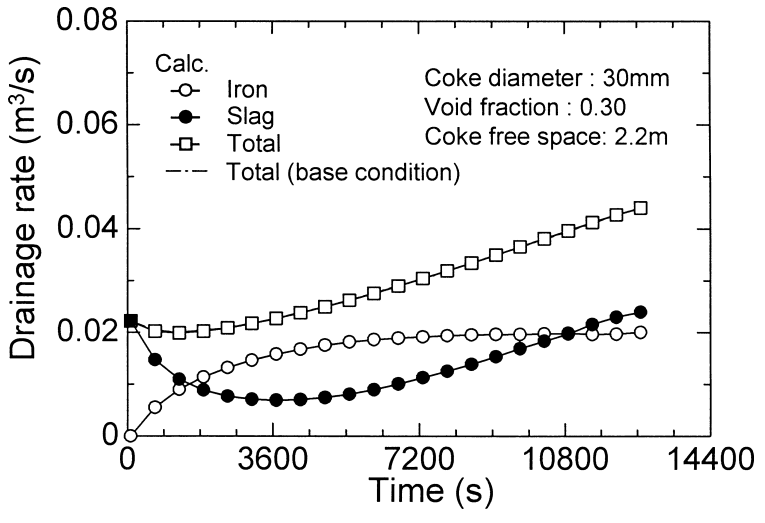

Fig. 8. Effect of coke free space on temporal variation of iron, slag and total drainage rate.

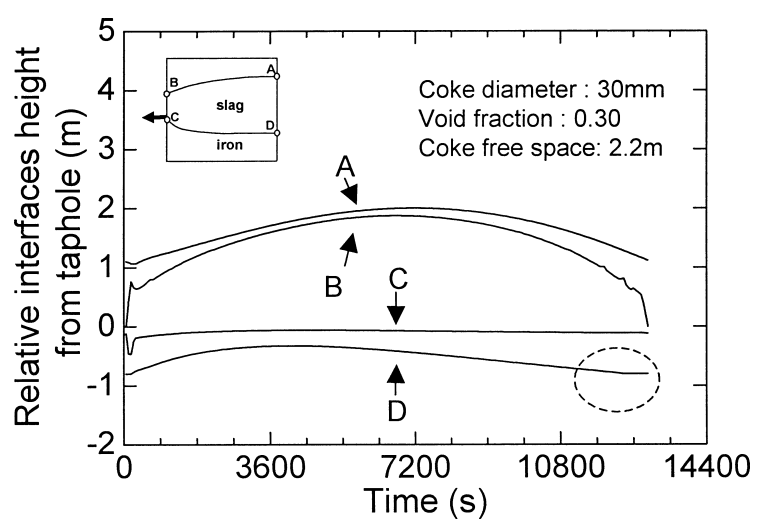

Fig. 9. Effect of coke free space on gas-slag and iron-slag interface height.

interfaces height with a $2.2 \mathrm{~m}$ of coke free space from the bottom of the hearth. As shown in Figs. 1, 8 and 9, there are no obvious differences in the drainage rates and interfaces height except that the lowest point of the iron-slag interface (line D) remains at the same level in about $12000 \mathrm{~s}$ (in Fig. 9), because the bottom of the iron-slag interface entered the coke free space. Therefore, a coke free space bellow the taphole has no obvious effect on the drainage behavior as Paul Zulli et al. reported in their paper. ${ }^{5}$

\subsection{Effect of Impermeable Zone in the Hearth}

Figure 10 shows temporal variation of total, iron and slag drainage rates, and Fig. 11 shows temporal variation of gas-slag and iron-slag interfaces with (1) $1.2 \mathrm{~m}$ of impermeable zone $(\varepsilon=0)$ from the bottom of the hearth (2) $2.2 \mathrm{~m}$ of impermeable zone from the bottom of the hearth. These conditions also correspond to a shallow blast furnace hearth of 1.8, $0.8 \mathrm{~m}$ respectively. As shown in Figs. 1, 10 and 11, there are no obvious differences in the drainage rates and interfaces height except that the lowest point of the iron-slag interface (line D) remains at the same level in about $12000 \mathrm{~s}$ in the case with the 2.2 of impermeable zone (in Fig. 11), because the bottom of the iron-slag interface reached the impermeable zone. Therefore, an impermeable zone bellow the taphole level has no obvious effect on the drainage behavior as well as a coke free space bellow the taphole level. 

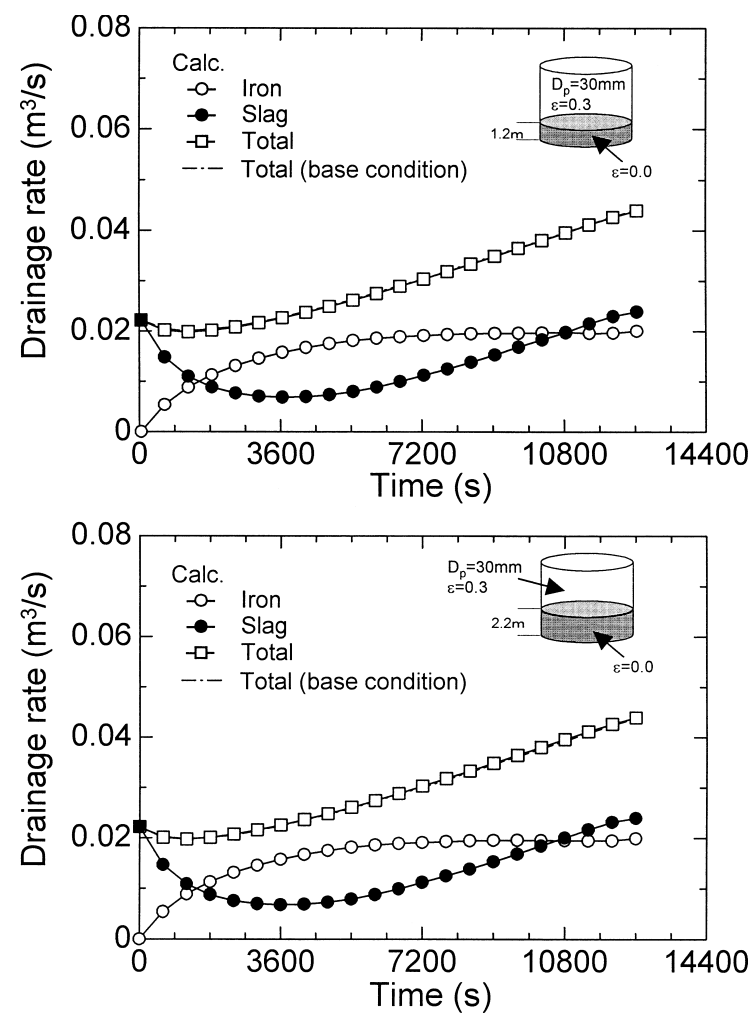

Fig. 10. Effect of impermeable zone on temporal variation of iron, slag and total drainage rate.
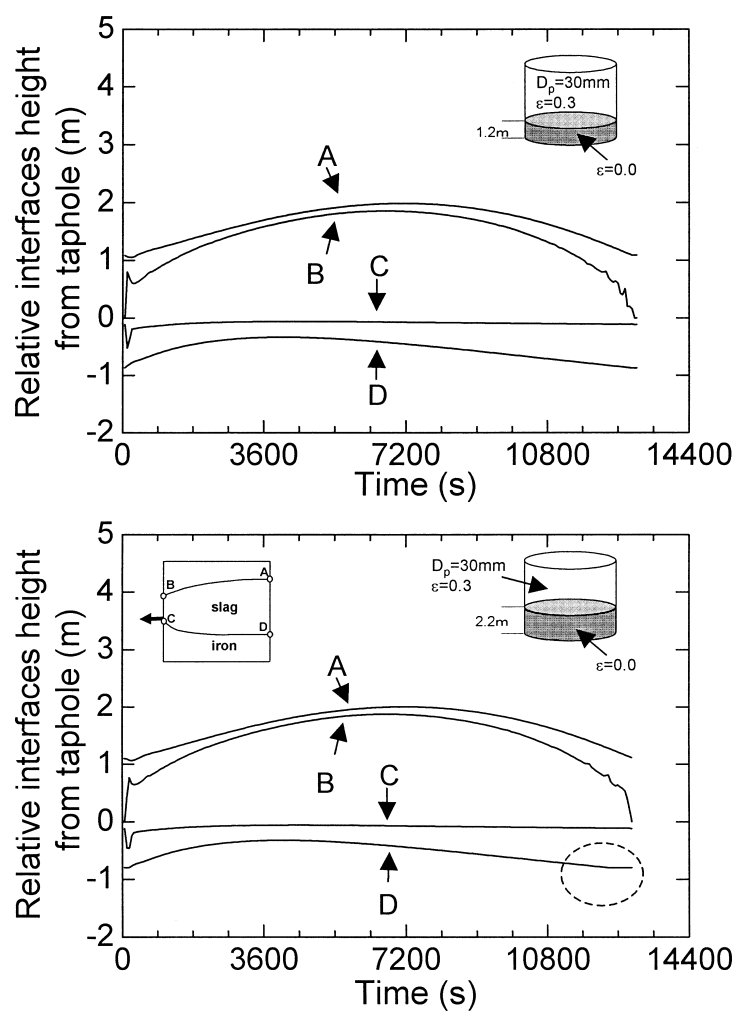

Fig. 11. Effect of impermeable zone on gas-slag and iron-slag interfaces height.

\subsection{Effect of Coke Diameter Distribution in the Hearth}

Temporal variation of total, iron and slag drainage rates, gas-slag and iron-slag interfaces height, terminal profiles, and residual iron and slag volume were investigated for 4

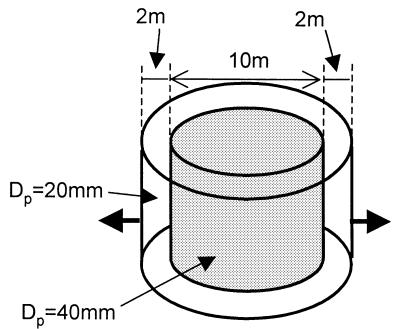

Case (1)

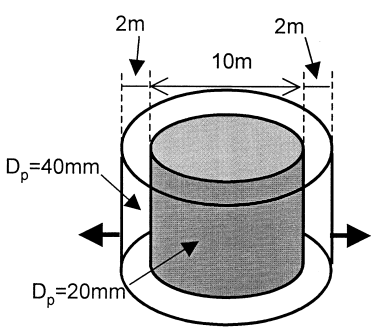

Case (3)

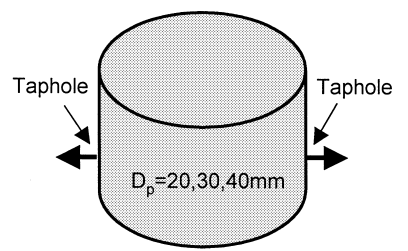

Case (2)

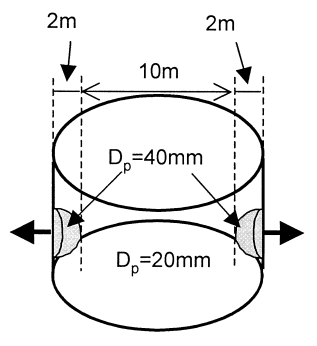

Case (4)
Fig. 12. Schematic drawing of coke diameter distribution for calculations.
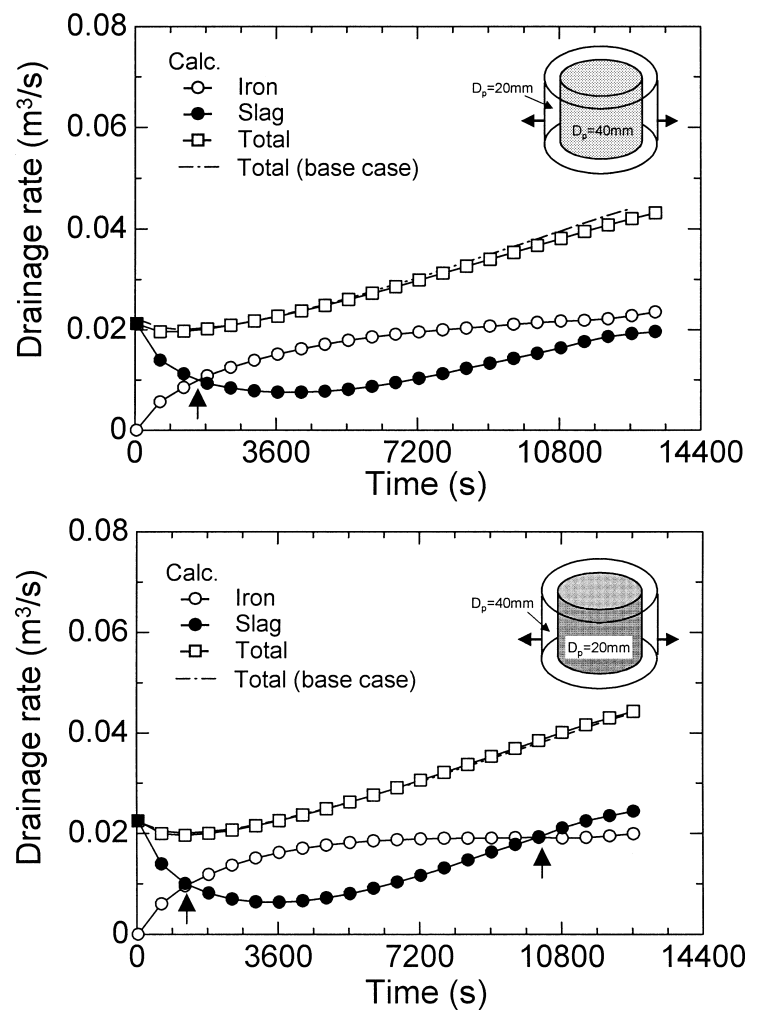

Fig. 13. Effect of packed bed structure on temporal variation of iron, slag and total drainage rate.

cases: (1) $20 \mathrm{~mm}$ of coke diameter in the peripheral region, $40 \mathrm{~mm}$ of coke diameter in the central region (2) 20,30 , $40 \mathrm{~mm}$ of uniform coke diameter, (3) $40 \mathrm{~mm}$ of coke diameter in the peripheral region, $20 \mathrm{~mm}$ of coke diameter in the central region, (4) $40 \mathrm{~mm}$ of coke diameter in the regions $2.0 \mathrm{~m}$ from the tapholes, $20 \mathrm{~mm}$ of coke in other region (Fig. 12). The volume ratio of the peripheral and central region is unity.

As the coke diameter of the peripheral region increases, two intersections of the iron and slag drainage rates move toward the beginning of the tap (Fig. 13). This behavior is 

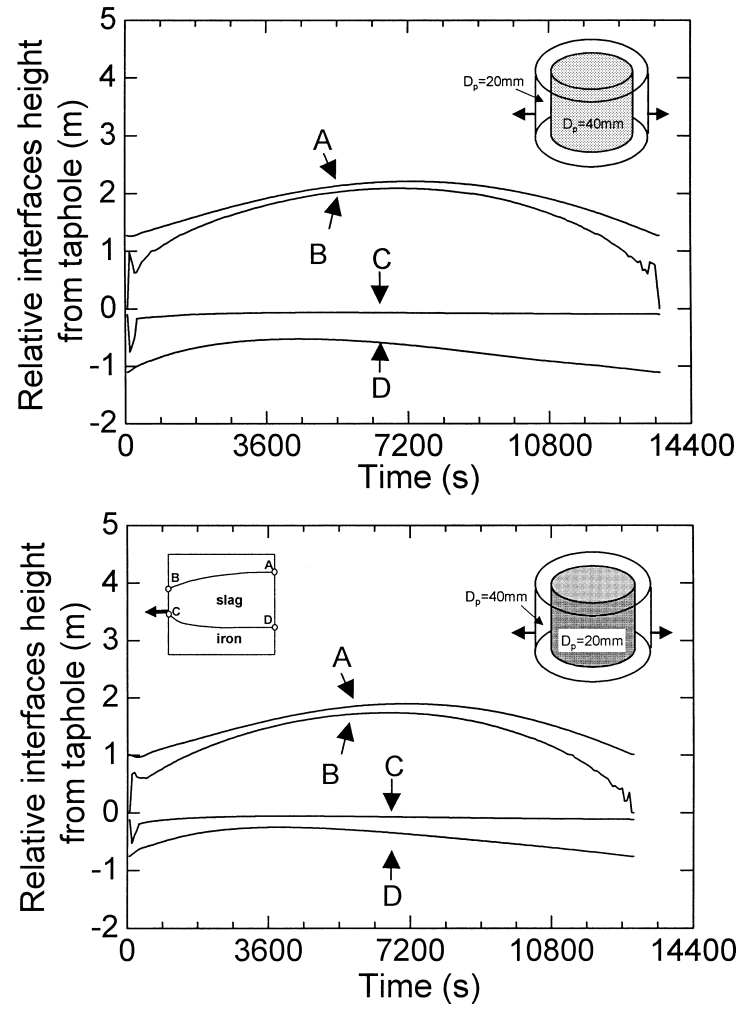

Fig. 14. Effect of packed bed structure on gas-slag and iron-slag interfaces height.

consistent with the uniform packed beds. Thus, the conditions of the peripheral region determine the drainage rate patterns of the iron and slag. In contrast, the coke diameter distribution has little effect on the total drainage rate as well as the coke diameter of the uniform packed bed, coke free space, and impermeable zone bellow the taphole level, because the maximum differences of the total drainage rates from that of the base condition is less than $5.0 \%$ in all cases.

Figure 14 shows temporal variation of gas-slag and iron-slag interfaces height during the tap with Case (1) $20 \mathrm{~mm}$ of coke diameter in the peripheral region, $40 \mathrm{~mm}$ of coke diameter in the central region and Case (3) $40 \mathrm{~mm}$ of coke diameter in the peripheral region, $20 \mathrm{~mm}$ of coke diameter in the central region, respectively. When the coke diameter distribution changes from Case (3) to Case (1), the highest point of the gas-slag interface (line A in Fig. 14) moves upward about $0.5 \mathrm{~m}$ in about $7200 \mathrm{~s}$. In contrast, the lowest point of iron-slag interface (D) moves downward about $0.2 \mathrm{~m}$ in about $7200 \mathrm{~s}$. Therefore, when the coke diameter distribution changes from Case (3) to Case (1), the slag layer expands both upward and downward, and the maximum slag layer thickness increases about $0.7 \mathrm{~m}$.

As shown in Fig. 15, the average thickness of slag and iron mostly depends on the coke diameter in the peripheral region. Therefore, for the reduction of the residual slag volume at the end of the tap, it is important to keep large coke diameter in the peripheral region, and the coke diameter in the central region is not so much important. Thus, the conditions of the peripheral region at the taphole level determine the residual slag volume, and the drainage rate patterns of the iron and slag.

The result of the case with $40 \mathrm{~mm}$ of coke in the region
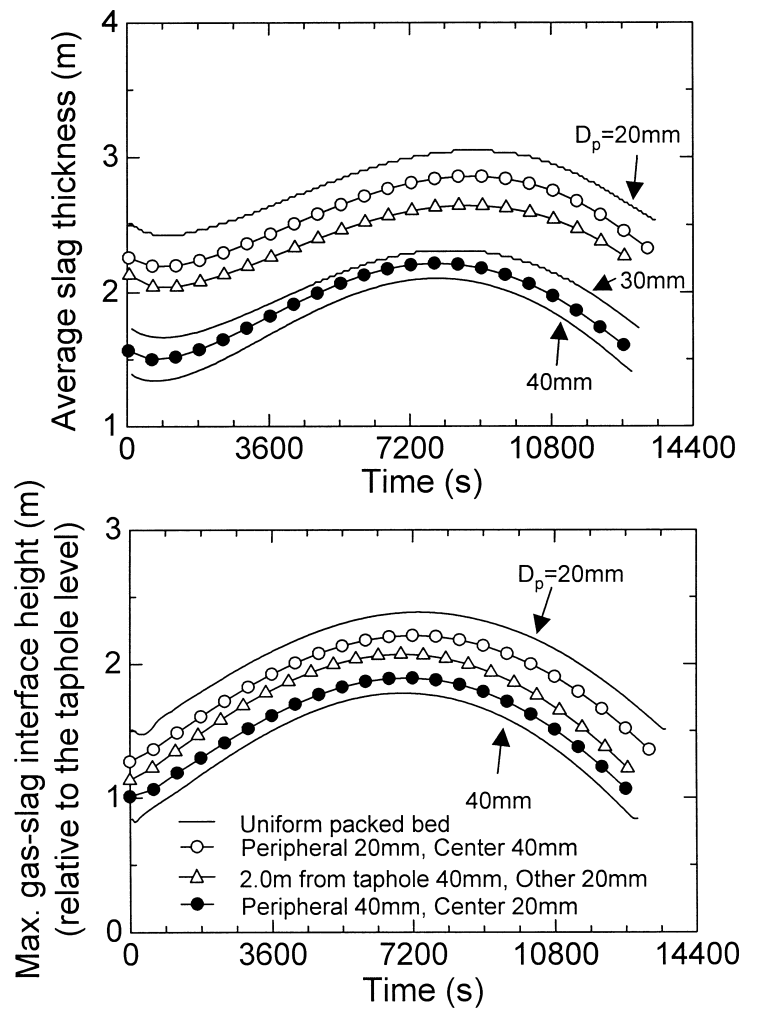

Fig. 15. Effect of packed bed structure on average thickness of slag and maximum gas-slag interface height.

$2.0 \mathrm{~m}$ from the taphole and $20 \mathrm{~mm}$ of coke in other region took almost mean position between the results of the case with 40 and $20 \mathrm{~mm}$ uniform packed coke. That means, the packed bed in the region, which is only about $4 \%$ of the volume in the hearth, has about $50 \%$ of contribution to the residual slag volume in the hearth. From these results, if the packed bed structure in the region can be controlled, considerable volume of the residual slag will be decreased.

\subsection{Effect of Slag Viscosity in the Hearth}

It will be very difficult to maintain a hearth temperature at low reducing agent rate operation. A decrease of the hearth temperature causes an increase of slag viscosity. The effect of slag viscosity on temporal variation of total, iron and slag drainage rates are shown in Fig. 16. The slag viscosities of $0.27,0.54,1.08 \mathrm{~Pa} \cdot \mathrm{s}$ correspond to the kinematic viscosities of $10 \times 10^{-5}, 20 \times 10^{-5}, 40 \times 10^{-5} \mathrm{~m}^{2} / \mathrm{s}$, respectively. The maximum difference of the total drainage rate between the case even with $1.08 \mathrm{~Pa} \cdot \mathrm{s}$ of slag viscosity and the base condition is only $10.5 \%$. Regarding the iron and slag drainage rates, as the slag viscosity decreases, one or two intersections of the iron and slag drainage rates move toward the beginning of the tap. Thus, the slag viscosity also affects the drainage rate patterns of iron and slag. However, there is no significant effect of the slag viscosity on the drainage rate pattern in an actual blast furnace operation, because, in an actual blast furnace operation, slag viscosity is usually maintained at a low enough value such as $0.27 \mathrm{~Pa} \cdot \mathrm{s}$ in this work. Therefore, the peripheral region's permeability can be predicted from the drainage rate patterns of iron and slag, if precise measurement of the drainage rate patterns can be achieved.

With increasing the slag viscosity, the maximum 

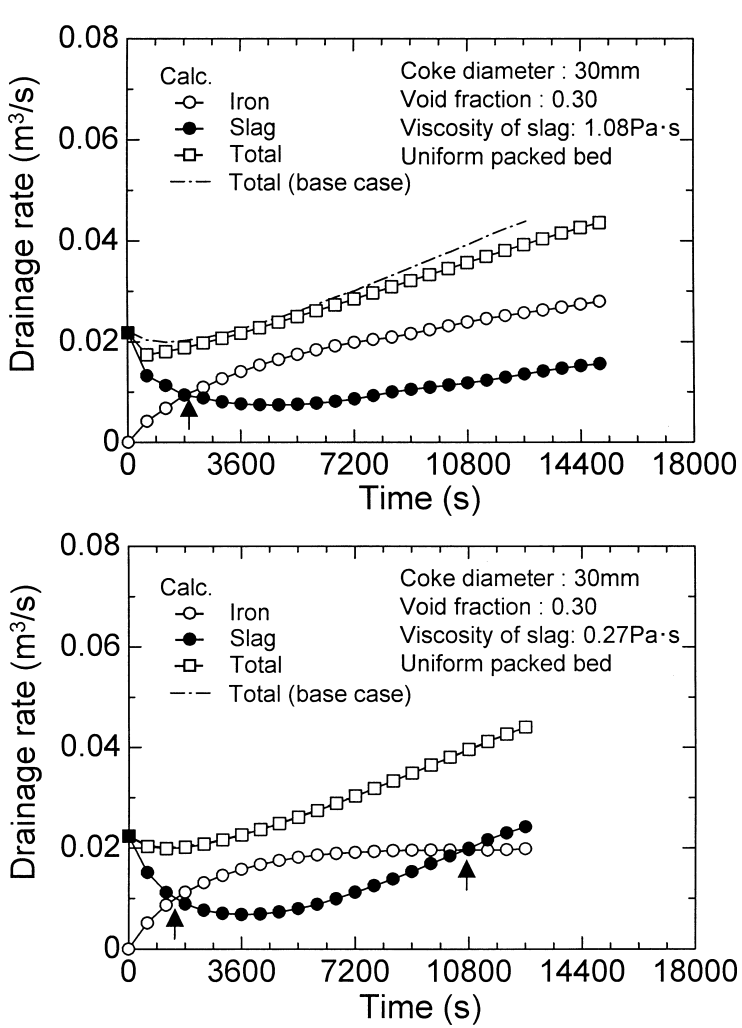

Fig. 16. Effect of slag viscosity on temporal variation of iron, slag and total drainage rate. Coke packed bed is uniform.

gas-slag interface level increased considerably. Fourfold slag viscosity causes about $0.9 \mathrm{~m}$ of increase in the maximum gas-slag interface level, about $0.5 \mathrm{~m}$ of decrease in the minimum iron-slag interface level. Especially, the lowest point of iron-slag interface (line D in Fig. 17) falls about $1.0 \mathrm{~m}$ at the end of the tap. The drainage time increased according with the increase of the slag viscosity, because the increase of the slag viscosity caused the increase of pressure drop in the taphole and the hearth, decrease of the total drainage rate.

As the viscosity of slag increases, the thickness of the slag layer becomes thicker, which means the slag volume increases (Fig. 18). The position of the gas-slag interface depends on the balance between gravitational force and the resistance to slag flow through a packed coke bed. An increase in the viscosity of slag causes an increase in the resistance. As a result, iron flows prior to slag and the slope of the gas-slag interface near a taphole becomes steeper. The coke diameter and the viscosity of slag have an opposite effect on the iron and slag volume. The results of the case that $60 \mathrm{~mm}$ of coke in the region $2.0 \mathrm{~m}$ from the taphole and $30 \mathrm{~mm}$ of coke in other region, $1.08 \mathrm{~Pa} \cdot \mathrm{s}$ of slag viscosity are also shown in Fig. 18. Doubling the coke diameter only in the regions $2.0 \mathrm{~m}$ from the tapholes has almost the same effect as decreasing the viscosity of slag to $1 / 2$.

\subsection{Effect of Taphole Location and Drainage Interval}

Numerical analyses were carried out to examine the effect of a taphole location (two tapholes do not locate 180 degrees apart from each other) and drainage intervals on drainage rates, drainage patterns, and residual iron and slag
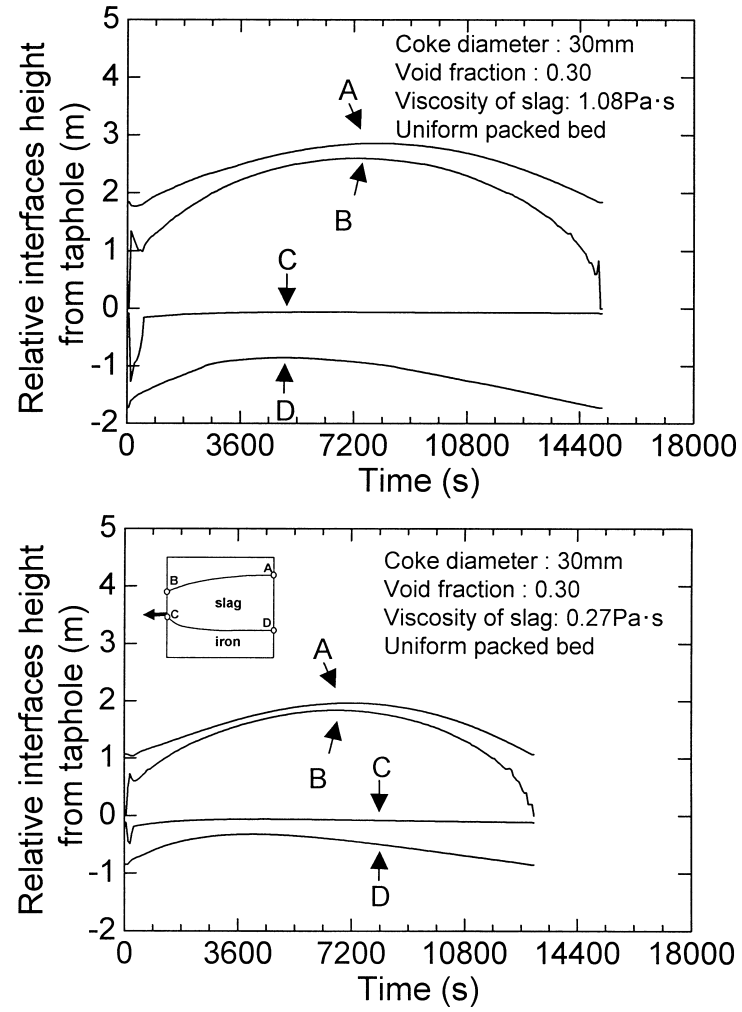

Fig. 17. Effect of slag viscosity on gas-slag and iron-slag interfaces height.
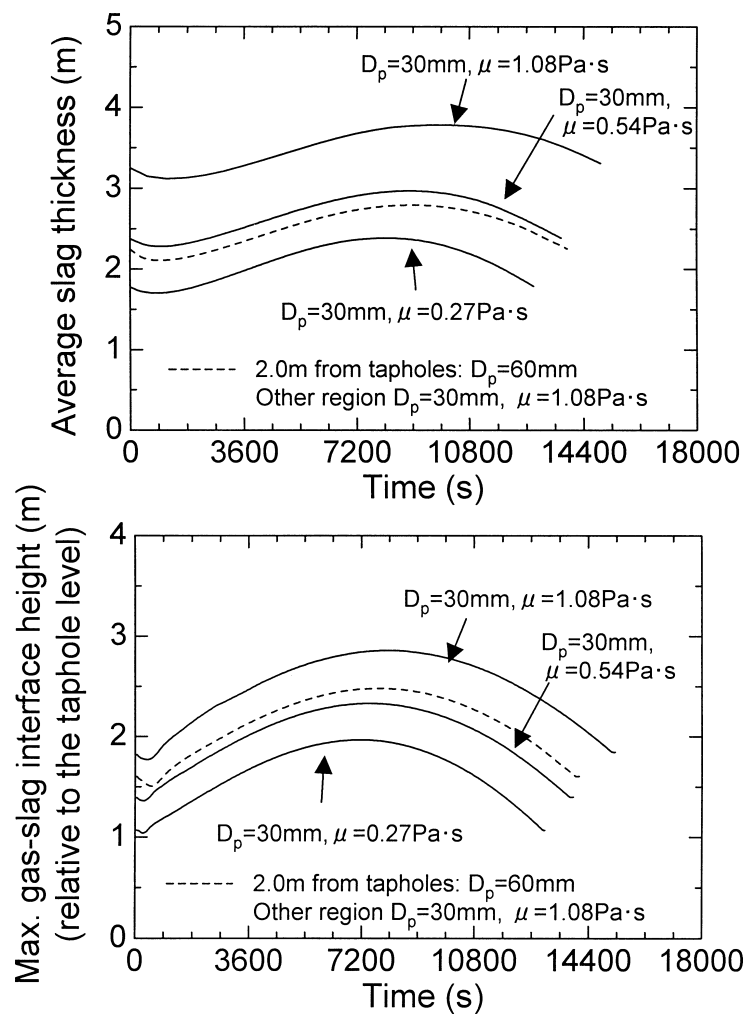

Fig. 18. Effect of viscosity and packed bed structure on average thickness of slag and maximum gas-slag interface height.

volume. The drainage interval of Kobe No. 3 blast furnace is $1620 \mathrm{~s}$.

Figures 19 and 20 show examples of temporal variation of total, iron and slag drainage rates and interfaces shapes. 

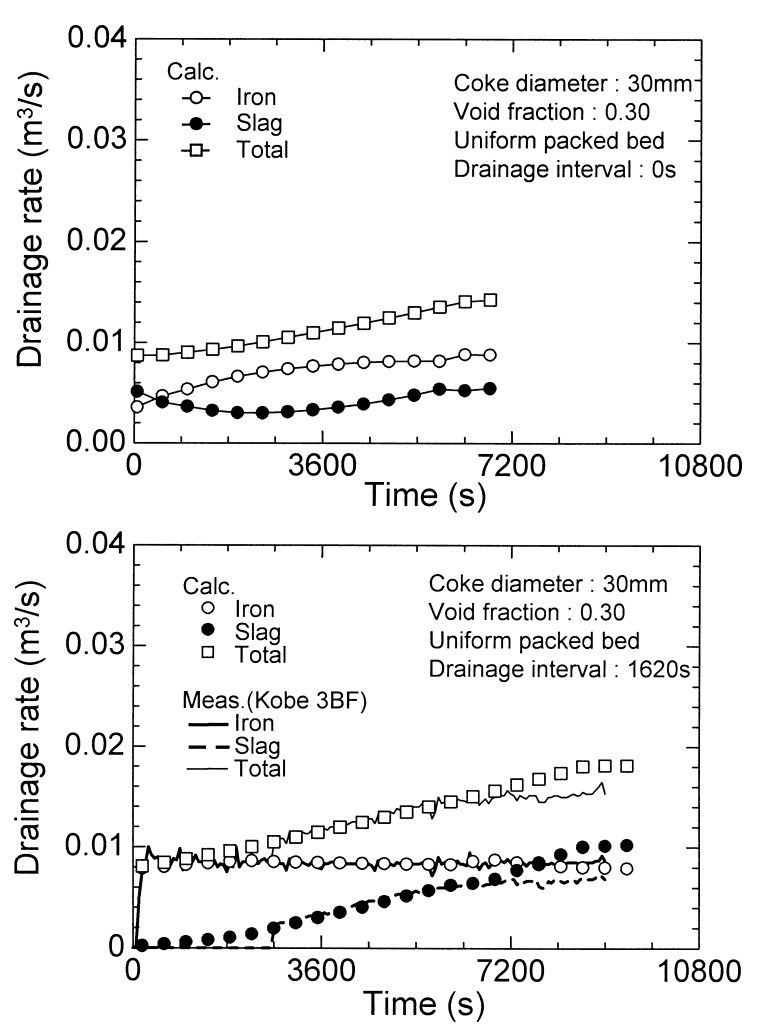

Fig. 19. Effect of drainage interval on temporal variation of iron, slag and total drainage rate.
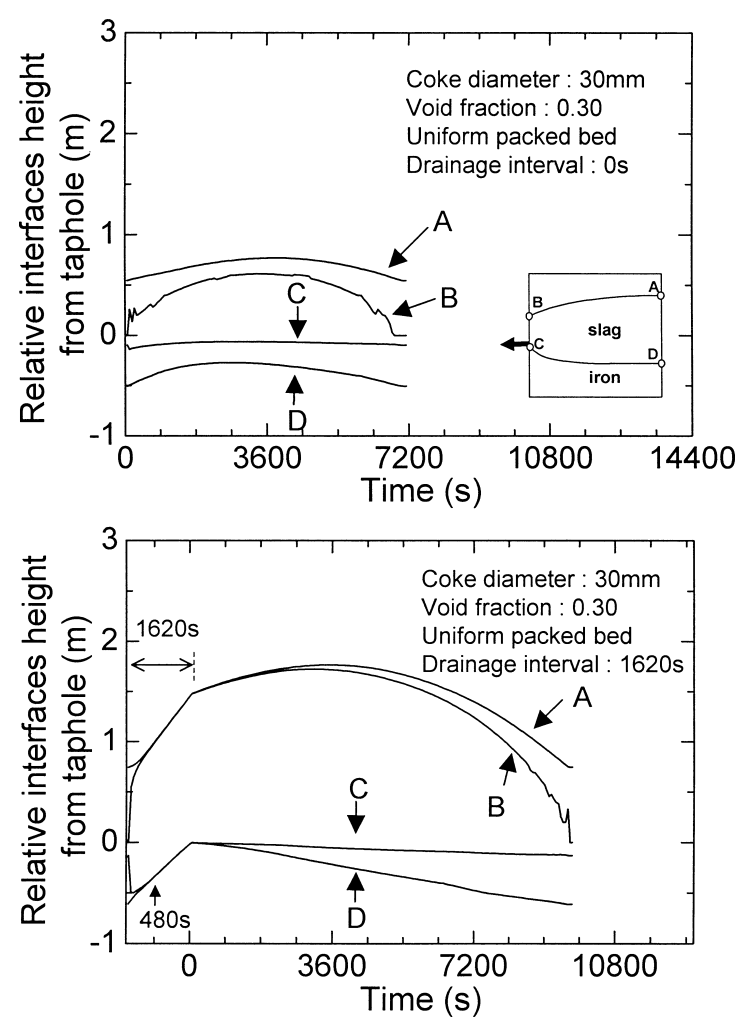

Fig. 20. Effect of drainage interval on gas-slag and iron-slag interface height.

The calculated and measured temporal variations of drainage rates are essentially identical in the case of $1620 \mathrm{~s}$ drainage interval. As increasing the drainage interval, such as $0,600,1200,1620,2400 \mathrm{~s}$, the drainage rate of iron at the beginning of the tap increased accordingly, and the

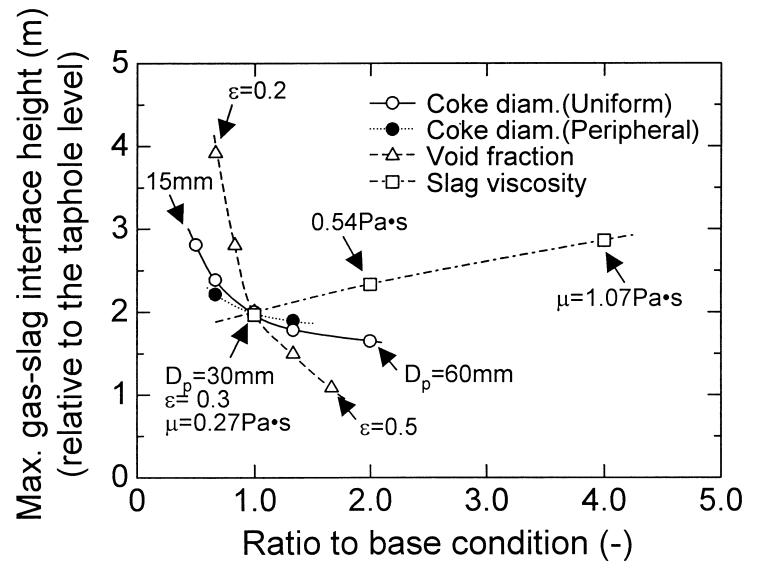

Fig. 21. Effect of various in-furnace conditions on the maximum gas-slag interface height relative to the taphole level.

drainage behavior changed from slag first tapped type drainage to iron first tapped type drainage. When the drainage interval is $0 \mathrm{~s}$, slag drains prior to iron because the average iron level is below that of the taphole at the beginning of the tap as in the cases of previous sections. However, as increasing the drainage interval, the average iron level at the beginning of the tap moves upward, and then exceeds the taphole level with a specific drainage interval. Thus, a drainage pattern, whether iron drains prior to slag or slag drains prior to iron, is largely affected by a drainage interval.

In terms of the gas-slag and iron-slag interfaces shapes in the case of $1620 \mathrm{~s}$ drainage interval, the both interfaces flattened in about $480 \mathrm{~s}$ after the stoppage of the taphole. Therefore, the result indicates that more than $480 \mathrm{~s}$ drainage interval eliminates the effect of the taphole location.

\subsection{Effect of Various In-furnace Conditions on the Maximum Gas-Slag Interface Height}

Figure 21 shows the effect of various in-furnace conditions on the maximum gas-slag interface height. The effect of coke free space and impermeable zone were not shown in the figure, because those effects on the maximum gas-slag interface height were negligible.

Increasing coke diameter and void fraction decrease the maximum gas-slag interface height. On the other hand, increasing slag viscosity increases maximum gas-slag interface height. The reason is that slag viscosity mainly contributes to fluids flow in the hearth as a pressure drop in the packed bed. In the Kozeny-Carman's expression, the pressure drop is proportional to the viscosity, and inversely proportional to the square of the coke diameter and $\varepsilon /(1.0-\varepsilon)$. Therefore, doubling the coke diameter counterbalances a fourfold increase in slag viscosity. Increasing coke diameter provides an increase of permeability in the hearth. Increasing void fraction in the hearth provides increases of both permeability and storage capacity for slag volume per unit volume in the hearth. Therefore, the maximum gas-slag interface height decreases dramatically by increasing void fraction. Varying the coke diameter from 30 to $25 \mathrm{~mm}$, slag viscosity from 0.27 to $1.08 \mathrm{~Pa} \cdot \mathrm{s}$ and void fraction from 0.3 to 0.25 are almost the same effect on the maximum gas-slag interface height. 


\section{Conclusion}

The influence of various in-furnace conditions on the drainage rates, the residual iron and slag volume and the maximum gas-slag interfaces height in blast furnace hearth were estimated using a three-dimensional mathematical model via predictions of the gas-slag and slag-iron interfaces shapes during drainage. The following results were obtained:

(1) The conditions of the peripheral region at the taphole level determine the residual slag volume. The packed bed in the region $2.0 \mathrm{~m}$ from the taphole, which is only about $4 \%$ of the volume in the hearth, has about $50 \%$ of contribution to the residual slag volume in the hearth.

(2) Increasing coke diameter and void fraction decrease the maximum gas-slag interface height. Increasing slag viscosity increases maximum gas-slag interface height. The void fraction change has the largest effect on the gas-slag interfaces height.

(3) The coke diameter distribution has little effect on the total drainage rate as well as the coke diameter of the uniform packed bed, coke free space, and impermeable zone bellow the taphole level. Under the terms of the conditions in this work, the void fraction and slag viscosity have also little effect on the total drainage rate, because the maximum variations of total drainage rate to that of the base condition were not greater than $11 \%$ in all cases. The taphole conditions dominate the total drainage rate under the terms of the assumed blast furnace conditions.

(4) The conditions of the peripheral region in the hearth determine the drainage rate patterns of the iron and slag. An increase of the permeability in the peripheral region moves one or two intersections of the iron and slag drainage rates toward the beginning of the tap. As far as slag viscosity is maintained at a low enough value such as $0.27 \mathrm{~Pa} \cdot \mathrm{s}$, the peripheral region's permeability can be predicted from the drainage rate patterns of iron and slag, if precise measurement of the drainage rate patterns can be achieved.

(5) As increasing the drainage interval, the drainage rate of iron at the beginning of the tap increased accordingly, and the drainage behavior changed from slag first tapped type drainage to iron first tapped type drainage. A drainage pattern, whether iron drains prior to slag or slag drains prior to iron, is largely affected by a drainage interval.

\section{Acknowledgement}

The authors gratefully acknowledge JFE Corporation and Kobe Steel Ltd. for supplying blast furnace geometrical and operational data.

\section{Nomenclature}

$D$ : Taphole diameter

(m)

$D_{\mathrm{p}}$ : Coke diameter

$e$ : Surface roughness of the taphole

$f$ : friction factor

$L$ : Taphole length

$\Delta P$ : Pressure difference between the inlet and outlet of the taphole

Re: Reynolds Number

$\vec{u}$ : Velocity of fluids

Greek Symbols

$\varepsilon$ : Void fraction

$\mu$ : $\quad$ Slag viscosity

\section{REFERENCES}

1) T. Fukutake and K. Okabe: Tetsu-to-Hagané, 60 (1974), 607.

2) T. Fukutake and K. Okabe: Trans. Iron Steel Inst. Jpn., 16 (1976), 309.

3) T. Fukutake and K. Okabe: Trans. Iron Steel Inst. Jpn., 16 (1976), 317.

4) W. B. U. Tanzil, P. Zulli, J. M. Burgess and W. V. Pinczewski: Trans. Iron Steel Inst. Jpn., 24 (1984), 197.

5) P. Zulli, F. W. B. U. Tanzil, Q. He, B. D. Wright, I. Bean and R. J. Nightingale: Proc. the 4th Int. Cong. Science and Technology of Ironmaking, Steel Institute VDEh, Düsseldorf, (2003), 482.

6) S. Watakabe, K. Takeda, Y. Sawa and T. Kawai: Tetsu-to-Hagané, 86 (2000), 301.

7) J. Torrkulla and H. Saxén: ISIJ Int., 40 (2000), 438.

8) H. Takahashi and H. Wakai: Tetsu-to-Hagané, 87 (2001), 373.

9) A. Shinotake, M. Ichida, H. Ootsuka and Y. Sugizaki: Tetsu-toHagané, 87 (2001), 388.

10) J. Brannbacka and H. Saxén: ISIJ Int., 41 (2001), 1131.

11) T. Nouchi, M. Yasui and K. Takeda: ISIJ Int., 43 (2003), 175.

12) K. Nishioka, T. Maeda and M. Shimizu: ISIJ Int., 45 (2005), 669.

13) P. C. Carman: Trans. Inst. Chem. Eng., 15 (1937), 150.

14) C. W. Hirt, B. D. Nichols and N. C. Romero: Los Alamos Scientific Laboratory Report, LA-5852, (1975).

15) C. W. Hirt and B. D. Nichols: J. Comp. Phys., 39 (1981), 201.

16) R. B. Bird, W .E. Stewart and E. N. Lightfoot: Transport Phenomena, John Wiley \& Sons, New York, (1960), 183.

17) T. Iida, H. Sakai, Y. Kita and K. Shigeno: ISIJ Int., 40 (2000), S110. 